\title{
Fair Treatment of the Victim in the Code of Criminal Procedure
}

\author{
Hassan Vahedi ${ }^{1}$ \\ ${ }^{1}$ Faculty of Law, Damghan Azad University, Iran \\ Correspondence: Hassan Vahedi, Faculty of Law, Damghan Azad University, Iran.
}

Received: April 29, 2017

Accepted: December 4, 2017 Online Published: October 30, 2018

doi:10.5539/ilr.v7n1p260

URL: https://doi.org/10.5539/ilr.v7n1p260

\begin{abstract}
Criminal justice institution undertakes the duty to investigate about legal cases and complaints, to issue the judgment and to enforce it on time through proper hearing and without any dely. Such actions can play an effective role in reducing the possibility of delinquency and victimization. As an essential element of procedure, victimization has not succeeded to recover its real right. Many criminologists have focused their researches on victims to solve the riddle of victimization and etiology of crimes. Criminologists also intended to assess victims' roles and shares in the process of crime commission. In addition, they intend to amend criminal provisions based on a victim-based approach to protect the victims through establishing new criminal institutions. Because of this, criminal justice system will change due to the effects of revolutions of victimization considered as the central core. This has led to an increase in paying attention to the victim's needs and rights in criminal system. The necessity of protecting the victim has not yet been recognized in Iranian statutes. This issue has not a place in criminology researches in Iran. However, we can observe the existing shortages in the area of protecting the victim and their status in Procedure Code through studying the victim's role. The author of the present article has studied the necessity of establishing special institutions to fill the existing gaps considered by Iranian legislator in New Criminal Procedure Code 2013. The author has also dealt with the protection of victims based on literature review, library search and related sources.
\end{abstract}

Keywords: victim, criminal justice, crime

\section{Introduction}

Crime has been a problem for human being throughout the history. Administration of justice has been one the wishes of humans that will be accomplished by approving the right to hear and defense in the light of a fair trial. Paying attention to the complainant's rights has been one of the issues in the area of law. Crime, offender and victim form three angles of criminal procedure from the commission of the crime to hearing stage and enforcing the verdict. Both parties entitle some rights according to the principle of fair trial. Presumption of innocence has been considered in the first step to protect the offender as long as the crime is proved. A new approach in criminal etiology has appeared alongside the revolution of criminology. This new approach has looked at the victim as another agent of victimization. In addition, lawyers have paid attention to the ways of protecting the victim in different stages of procedures. Consequently, protective criminology paid attention to the concerns and new institutions in the laws of criminal procedure of developed countries more than ever. In addition, this new filed of criminology has regarded the victim in different stages of criminal process from the beginning of the investigation to enforcement of punishment. Many changes occurred in the victim's role and status in the criminal procedure in favor of the victim to secure his or her rights. Article 11 of Criminal Procedure Code of Revolutionary Courts and Courts of General Jurisdiction in Criminal Matters 1999 has considered it a necessary to observe due process of criminal procedures. They include submitting the petition, paying related costs to demand compensation and the like. Article 9 of Criminal Procedure Code of Revolutionary Courts and Courts of General Jurisdiction in Criminal Matters 1999 has disregarded the distinction between the private complainant and claimant. The above Article holds: "an individual is known as a private claimant or a complainant when he or she incurs a loss and damage and/or entitles a right such as retaliation and false charge of fornication and demands the right." Because of this reason, we face private complainant and claimant in some cases and we observe private claimant in other cases in Criminal Procedure Code of Revolutionary Courts and Courts of General Jurisdiction in Criminal Matters 1999 (Ashori, 2009, p. 247). 


\section{Semantics}

\subsection{Criminal Procedure}

We can define criminal procedure as a collection of the following: provisions and rules stipulated for discovering the crime; prosecuting the accused; preliminary investigation; mediation; compromising between the parties; method of investigation; issuing the judgment; ways of objecting the judgment; enforcing the judgment; determining the duties and authorities of judicial officials and officials of justice department, and observing the rights of the accused, the victim and the society.

\subsection{Victim}

In Persian, the word "victim" is equal to the Arabic word for ghorbani (a scapegoat), the person against whom a crime has been committed and the injured party (Dehekhoda, 1998, p. 20335 \& Jafari Langrudi, 1998, p. 3232). The word victim has been used in the same meaning in English. It has different definitions in the literature of criminology and legal textbooks. In general, we can divide the definitions into broad and narrow ones. A broad definition emphasizes on incurring the loss and damage to others rather than on the original cause of loss and damage and causes of the crime. According to this viewpoint, a victim is a person who has incurred a definite damage and loss on his or her integrity so that most people of the society admit it (Jina Filzola, Kurd Ali Vand et al., 2000, p. 96). We should refer to the usage of the word "person" in the above definition. The person includes both legal and natural persons. Conversely, a narrow definition pays attention to the origin and the source of the loss.

Article 1, Section I of UN General Assembly Declaration of Basic Principles of Justice for Victims of Crime and Abuse of Power 1985 has defined the victim as "persons who, individually or collectively, have suffered harm, including physical or mental injury, emotional suffering, economic loss or substantial impairment of their fundamental rights, through acts or omissions that are in violation of criminal laws operative within Member States, including those laws proscribing criminal abuse of power."

Iranian legislator has made a distinction between private claimant and complainant in Article 10 of New Criminal Procedure Code 2013 for the first time. The same Article holds: "A victim is a person who incurs the loss and damage from the commission of the crime and if he or she demands for prosecution of the offender, he or she is known as complainant. Moreover, when demanding for compensation of loss and damage, he or she is called private claimant."

\section{Preliminary investigations}

Preliminary investigation is a collection of measures taken by special judicial officials to discover the crime, to collect and prevent the accused from fleeing or hiding and to give an opinion regarding whether he or she is prosecutable or not.

\subsection{Victimology}

Victimology is a branch of criminology where the researches are based on the victim so that the role of his or her personality is specified in forming the crime.

\subsection{Criminal Justice and Fair Trial}

Fair trial refers to the procedural aspect of justice in investigation and is one of the basic and fundamental rights of human. Fair trial is a descriptive expression and we should examine each of its components to present a precise definition of it. Trial has been used in the following meanings: (a) "to examine and make a judicial decision on issues existing between parties to a legal case by a competent court, whether they are questions of law or those of fact"; (b) "judicial investigation on questions of fact and of law between parties in a civil or criminal case before a competent court" (Fazaeli, 2010, p. 47). Meaning of fair, as the second part of the expression is equal to "an even conduct and according to the rules and laws when dealing with every person or a party" or means "reasonable and fair or appropriate with the circumstances". However, in judicial literature and legal writing, it is a description of neutrality and correctness, lack of bias and prejudice and personal profit, evenhandedness and justifiable between parties (Ibid., p. 50). A fair trial is a collection of standards and safeguards that have been predicted to observe the rights of parties in the procedure. Moreover, the case should be initiated before a competent, unbiased and independent court that is predictable in judicial mechanism (Rostami et al., 2009, 89).

\subsection{Standards of Fair Trial}

Fair trial contains various mechanisms that every person can use in a procedure whether civil or criminal. Some of the mechanisms are common and include the right to litigation, the right to access to impartial and 
independent courts and the like. They are applicable in different kinds of civil and criminal cases. Some other mechanisms include the presumption of innocence and arraignment which are applied in criminal cases.

A) General safeguards

General safeguards include the followings: right of litigation; independence and impartiality of judicial forum; equal facilities and enough time for defense; right to be present at the court when the case is heard; right of appeal; right to have an open trial; right to hear in a reasonable time and the principle of reciprocity.

\section{B) Safeguards for criminal cases}

The followings are the rights of the accused in criminal procedure: presumption of innocence, arraignment, employing a lawyer, having a translator, legality of imprisonment, prohibition of arbitrary attachment, right of silence, right of compensation to administer justice, prohibition of double punishment.

\subsection{Historic Trend of Victim Protection}

Determining the status of the victim from a criminal perspective is one of the bases of the study of victimization. The lawyers have dealt with two theoretical and practical viewpoints to study criminology and to present various definitions. We can observe some important documents when we study the historical trend of victim protection. They include victimization and victims of abuse of power and universal standards to protect victims. There are two normative documents in the UN criminal policy. We can consider the above documents international charters for the rights of victims of crimes. They include UN General Assembly Declaration of Basic Principles of Justice for Victims of Crime and Abuse of Power 1985, and UN Basic Principles and Guidelines on the Right to a Remedy and Reparation for Victims of Gross Violations of International Human Rights Law and Serious Violations of International Humanitarian Law 2005. Moreover, we can study the interaction of the movement of human rights with the movement of protecting victims in the 20th century as an academic research. It is in connection with international law of human rights as an independent filed of science from victimization. Such a major of science played some roles in the goals of human rights movement. Besides, some leading lawyers defined it as a violation of human rights in the World War II when they have been victims of such crimes (Raiijian, 2009, p. 87). Cesare Lombroso's book entitled "Criminal man" had a great impact on the way we look at the victims throughout history and forming deep scientific viewpoints about crime. It revolutionized the field of criminology many years later. Criminologists have focused their researches on victims to study their roles in the formation of crimes. The above surveys paved the way for a new scientific field to appear as scientific victimology. Formation of criminology in the 1940s has opened a new horizon for many scientists. Nevertheless, promoters of criminology became aware of its vital role. Some criminologists have emphasized on the importance of the study of the relations between offenders and victims and consequences of crime such as Hans Von Hentig, Benjamin Mendelsohn and Henry Henberg. Victimological criminology whose base is focused on the study of victims is the newest branch of theoretical criminology and studies the features and performance of victims. It also examines victims' relations with the perpetrator and criminal acts and their roles in commission of the crime. The victim, as a forgotten angle of a crime, has gradually entered the surveys of criminologists and criminal lawyers. In addition, it has attracted some attentions in criminal sciences in legal and experimental aspects (Raiijian Asli, 2011, p. 116).

Victimological changes have brought about some rights for victims in Iranian laws during recent years. They include the right of protecting victims against the accused, right of getting access to information about any session of the court, right of presence in all sessions of the trial, right to be heard, right of counsel with the government attorney, right of due and complete compensation, right of hearing without delay, right of dignity-based treatment with the victim (Mahmoud Saber, 2009, p. 145).

New Criminal Procedure Code 2013 typically intends to observe the principles and standards of the rights of citizenship and human rights through numerical, procedural and substantive changes and the way of prosecuting the accused. It also tries to enforce fair trial system for complainant, accused, victim, witness, informant, lawyer and the like in the process of criminal procedure on May 3, 2013 in 570 Articles and 230 Notes and Islamic Consultative Assembly approved it. The above Act has omitted many obstacles and limitations stipulated in defense and the way of presenting the accused. It has founded its principles on the followings: necessity of having a lawyer, a lawyer's right to defend the accused as his or her client and the necessity of arraignment of legal rights of the accused and criminal prosecution in favor of the victim by judicial forum and officers of department of justice in all criminal affairs. The new Act has some objections and defects but it enjoys some positive aspects and points in terms of observing sanctions of administering a fair trial. If it does not experience great changes, it can play an effective role in securing the rights of citizenship and fundamental rights and victims of Iranian society with the help of some by-laws. It can also use the professional experiences of experts, 
judges, and lawyers of department of justice. Principles of a fair trial are important principles of legality of crime and punishment. Articles 1 to 7 and some other Articles of New Criminal Procedure Code 2013 have dealt with such principles. Its main aim is to protect the rights of the victim, the accused and society. The vital necessity of fair treatment in judicial courts and related forums made Iranian legislator introduce every action that bars administration of justice in every stage of procedure as a crime against judicial justice (Ghorbani et al., 2014, p. 2).

\section{Victim's Rights}

Informing the victims of their rights and providing him or her with getting access to such rights are considered his or her important rights. Nevertheless, we should mention that such action is carried out in different forms. "Informing victims about their roles and their domains, scheduling, process of progression of hearing and the status of their files, especially in serious crimes, and when they demand such information are important duties" (Raijian Asli, 2011, p. 126). Nowadays, guidance institutes and judicial assistance have been established in department of justices in Iran. Such establishments use experts and experienced people to respond victims' needs and provide them with necessary information regarding how their files are correctly followed up. Besides, they draw up complaint, and present them some other information that help the victim obtain his or her rights. In addition, guidance and social working in police station in Iran, establishment of Case Management System (CMS) in all departments of justice paved the way to move towards upgrading victims' rights. This issue made it easy for parties to get access to necessary information. Another initiative was to form a center to respond and rehabilitate electronic services of the Judiciary from June 2005 so that victims can receive legal counsel (Beigi, 2007, pp. 32-400).

\subsection{Right of Protection from Victim against the Accused}

When a victim encounters his or her offender in the process of criminal procedure, it often makes them a double victim. This is also the case for their witnesses. Although such possibilities exist, we should avoid encountering victims and their witnesses with the accused. If such action is unavoidable, some protective measures should be taken for this group of persons. Victim's right of protection against the accused is included in his or her rights. After submitting the complaint, the victim is likely to be put under pressure by the accused, their relatives or friends to delay and/or to deviate the process of procedure. Therefore, criminal justice system is obliged to protect the victim against the pressures or harms impaired by the accused. Such protection can be accomplished by physical protection, establishment of a safe environment and/or accompaniment of police in the court before or after the hearing. The governments should try to take necessary measures throughout the legal process by means of judicial and administrative methods to provide assistance for the victim. Other manifestations of protection of victims against the accused includes the followings: using some actions to reduce hardship and troubles for victims; safeguarding victims' private lives when necessary and providing security of victims and their families and witnesses against retaliation and revenge (Ebrahimi, 1995, 2960).

\subsection{Right of Information about any Kinds of Court Sessions}

A victim has a right to be informed about any kinds of court sessions for hearing and the decisions made in this regard. The sessions are various. One session is dedicated to the study about the criminal event and treatment done by the offender that causes damage to the victim. The victim should be aware of such sessions to declare their opinions on time. Some other sessions may be held to examine the crime. Other sessions may be related to the study about granting provisional freedom to the accused, offender or the victim. The victim should be aware of such kinds of sessions because the authorities may decide to make the offender free. Hence, the victim should declare his or her opinions in the sessions. Moreover, the victim should be aware of every session that leads to the freedom of the accused.

\subsection{Right of Presence in All Sessions of Procedure}

The victim has a right to take part in all sessions of the procedure. Enforcing such a right is so important that we cannot consider a session fair without enforcing it. Victim's presence make him or her speak about the damages and harm impaired by the offender when necessary. Meanwhile, the victim becomes aware of the process of the issues posed in the court. Regarding this fact that the victim is considered as a witness in all sessions of the procedure in criminal justice system, their presence paves the way for them to take oath to prove their claims.

\subsection{Right to Be Heard}

Right to be heard means the victim's assertions and statements should be regarded and heard in all stages of judicial processes, especially in the hearing session. Victims' rights include to permit their presentation and to regard their viewpoints and concerns in the appropriate stages of procedure without partiality towards the 
accused. Besides, they should be compatible with the related internal criminal justice system. The right to be heard is logically enforceable when the victim can speak in a hearing session and their statements are taken into consideration. In other words, we should regard it as the right to speak (Paragraph 11 of Article 3 of Establishing Public Prosecutor's Office and Article 193 of New Criminal Procedure Code 2013).

\subsection{Right to Counsel with Government Attorney}

The victim has a right to counsel with an attorney appointed by the government to pursue the public prosecutor's claim. Government attorney cannot avoid presenting legal assistance to the victim because they undertake power of attorney on behalf of the government rather than the victim. Such a right is considered because the public prosecutor can appoint an attorney for themselves to submit and pursue cases in the courts. The appointed attorney performs all duties on behalf of the public prosecutor after he or she decides to take action and to charge a person. Right of the victim's counsel with the government's attorney does not mean that the victim has a right to interfere with the public prosecutor's duties (Shiri, 2006, p. 146; Hashemi, 2007, pp. 68-105). The victims should utilize assistance of persons familiar with legal and judicial affairs to recover their legitimate rights and to pursue their case under the best circumstances. Attorneys of the department of justice are those who can assist the victims the most. According to the provisions of Iranian criminal procedure, Article 69 of Criminal Procedure Code 1999, determining an attorney by the victim has a determinative aspect. In addition, the victim can get access to an attorney from the beginning of the criminal procedure to the end of it. No one can deny the necessity of the presence of an attorney accompanied with the victim in criminal process.

\subsection{Right of Objection and Appeal}

One of the obvious rights of the victim is objection and demand for appeal for the issued judgment. Present Iranian system of investigation contains two-stage procedure and accordingly, some of the judgments are appeasable. The aim of stipulating such provision is to protect victim's rights. The followings are the circumstances where a victim can appeal: 1- objection to injunctive relief and order of non-suit based on Paragraph 13 of Article 3 of Act for Establishment of Revolutionary Courts and Courts of General Jurisdiction 2002 and Note of Article 232 of Criminal Procedure Code 1999; 2- acquittal judgment and the victim's objection to it based on the Note of Article 232 of Criminal Procedure Code 1999; 3- judgments issued by provincial criminal court and the status of the victim to object to them according to Paragraph 3, Note 5, Article 20 and Note of Article 232 of Criminal Procedure Code 1999 and Article 26 of Amendment Act for Establishment of Revolutionary Courts and Courts of General Jurisdiction 2002.

\subsection{Right of Due and Complete Compensation}

Compensation is regarded one of the most important of victim's needs. The damaged impaired to the victim is recovered by compensation. Moreover, compensation shows that the offender recognizes his or her mistake. Compensation is something beyond remedy, because remedy is considered as one of the manifestations of compensation.

\subsection{Right of Due Hearing and without Delay}

The court sessions should be held without any unreasonable delay. The faster the criminal justice system can examine the harm and needs of the victim after commission of the crime, the more it will help the victim to reduce the harm and damage inflicted (Siegel, 2009, p. 78).

Facilitation in examining the victim's status and holding court sessions without delay does not mean that the accused rights should be disregarded and/or breached. Rather, the court is obliged to make adjustment and balance between the accused's right of defense in a court session and the victim's right to hold the court sessions fast. Besides, invocation to this right does not mean that the authority should be in the victim's hands so that the accused's right of a fair trial and the government's right to hold hearing sessions are breached.

\subsection{Right of Dignity-Based Treatment with the Victim}

Respect to the dignity and human honor is one of the basic rights of any human being. Every human being should be treated with respect and observance of dignity and honor regardless of color, race, religion, whether they are victims or offenders. A victim has a right that people treat him or her with respect. Observance of respect and dignity-based treatment with the victim is regarded as one the standards of a fair trial. "Dignity-based treatment means to deed the victim with respect, appreciate them and to deal with them appropriate to human status and dignity (Shiri, 2007, p. 18). Victim's right to be treated with honor is so important that we can say that if it is not enforced, double victimization will be imposed on the victim as an intangible result of the processes of criminal justice system. 
Some behaviors are regarded as conducts that are far away from the victim's dignity and status in criminal justice system. As an example, police has been trained to deal with the offender in all places but it has not been trained to make a connection with the victims. A victim's property may be taken into custody for months to be presented in the court as evidence. The reason is that the victim is the only one who can recognize the robbed property and the offender. Victims come to the court hearings and are investigated in tough manners, even harder than the accused (Wrobieski \& Hess, 2003, p. 95).

Because of this, observance of victim's dignity and privacy and a kind of treatment accompanied with sympathy are manifestations of fair treatment in New Criminal Procedure Code 2013. Moreover, when dealing with the victim, observance of fairness is regarded as their rights. Preserving the victim's human dignity plays an effective role in reducing the dark figure of victimization and consequently, in delinquency. The reason of the above argument is that to respect the victims causes them to have more inclination to refer to criminal justice system. Moreover, such action gains confidence of the victim towards the system (Ebrahimi, 2005, p. 294).

\section{Judicial Solutions to Protect the Victim in Laws}

\section{A) Protecting the victim in preliminary investigation}

As the first stage of investigating a crime, preliminary investigation stage, starts at the public prosecution's office. The investigator carries out other related examinations of the crime and refers the case to the public prosecutor. Iranian legislator has stipulated Article 37 of New Criminal Procedure Code 2013 to protect the victim in the first stage. According to the above Article, officers of the department of justice are obliged to accept oral or written complaints during 24 hours of a day. An oral compliant will be written in process-verbal (minutes of the meeting) and the complainant signs it. If the complainant is illiterate or cannot sign, arrangements are written in the process-verbal and will all be certified with oral complaint. Officers of department of justice are obliged to submit a receipt to complainant after receiving the compliant and send the file to public prosecutor promptly. New Criminal Procedure Code 2013 has gone far away from investigative procedural system through using comparative studies and following a fair trial. In addition, laws related to the protection of the offenders and the victims have changed a lot (Hosseinlu, 2003, p. 56). Article 37 of New Criminal Procedure Code 2013 reminds us of a Principle of Iran's Constitution 1979. The Principle stipulated that submitting complaints to judicial forums is a common right of Iranian people. Although the victim is an important element in criminal process, he or she cannot play a direct role in International Criminal Court to initiate an action. Nevertheless, Criminal Code has given him or her opportunity in preliminary investigation stage to submit a complainant about the public prosecutor's decision about the initiating the investigation. The victim can also give his or her opinion about the lack of investigation or initiating an investigation in preliminary stage (Babaii, 2010, p. 87).

In another stage, Iranian legislator in Article 28 of New Criminal Procedure Code 2013 obliged public prosecutor to train the officers. The reason is to protect the victim in preliminary investigation, to observe the presumption of innocence and to honor the rights of citizenship. Women officers should undertake the investigation of women and minors in investigation and questioning stages. Specifically, officers are obliged to prevent from any delays and wasting the victim's rights. If this rule is breached, it will have criminal sanction. Sometimes, investigations are carried out without public prosecutor's knowledge and it is authorized. According to Paragraph 10 of single-clause bill of the Act for Observing Legitimate Freedom and Preserving Rights of Citizenship 2004, investigations and examinations should be based on scientific and legal principles and methods. According to the above provision, authorities should accomplish previous training and necessary supervision. Moreover, the law has predicted severe punishments for those who ignore arrangements and provisions and enforce unlawful ways to carry out their duties. Paragraph 3 of the single-clause bill has emphasized the necessity of the presence of an attorney in all stages of investigation. It also mentioned the observance of the right of employing an attorney by the courts and public prosecutor's office. The above judicial forums are obliged to observe the right of defense for both the accused and the complainants (victims). They should also provide them with an opportunity to use an attorney and an expert. In Article 43 of the same Act when there is a doubt about the evidence and presumptions related to the commission of the crime, investigations should be carried out without the public prosecutor's knowledge and without any right of questioning and inspection. Officers are obliged to carry out their duties regarding the obvious crimes once they are aware of them promptly. They should inform the public prosecutor the issues and he or she will issue necessary orders to continue investigations. The same officials should inform public prosecutor commission of non-obvious crimes before every action is done in order to gain information and to start investigation. They are supposed to go on with the investigation without any delay.

New Criminal Procedure Code 2013 stipulated that public prosecutor should be present in the stage of investigations and this shows that the same Act protects victim. Another solution in the above Act is the judge's 
obligation to study the case to see if it is incomplete in terms of evidence. The judge should vest the incomplete file to public prosecutor and/or related officers to examine. Meanwhile a proper security should be collected from the accused (Tadayon, 2017, p. 56). All of the above investigations should be accomplished promptly even in holydays (Ashuri, 2009, p. 247). Depending on the kinds of the crimes, an investigator should merely investigate some crimes. Public prosecutor should investigate some other crimes in the absence of investigator and/or through training the officers of department of justice. Other circumstances of protection of victims include the introduction of witnesses, presentation of existing evidence, study of the process-verbal drawn up and other documents of the file. All of these documents should be incompatible with the necessity of discovering the truth. New Criminal Procedure Code 2013 even indicates that there should be a possibility for the victim to copy the documents at his or her own expense. Comparing this point with those stipulated in the previous Acts, we find out that there are some changes in viewpoints with respect to the victims in the above Act. Furthermore, we find out that the step taken by Iranian legislator to change the Act is so great and in favor of the victim to some extent in securing the victim's rights in preliminary prosecution.

B) Protection of victim in trial stage

Courts are open in Iranian judicial system to inform people about fair trial and their supervising a correct trial. Principle of openness of the courts is excluded under some circumstances based on Article 352 of New Criminal Procedure Code 2013. According to the recognition of the court and after public prosecutor presents his or her opinion in the following circumstances, the court will be held in camera: cases carrying crimes against honor and public good; cases of family matters or forgivable claims based on the parties' demand, and when openness of the court causes disorder in security and destroys religious feelings. By openness of a court, we mean there is no obstacle for people to present in trial sessions. Thus, based on Article 353 of New Criminal Procedure Code 2013, journalists and media can come to the court, provide written report and publish it. Nevertheless, they should not mention the names and particulars that make personal identity or administrative and social status of the victim and those of offender obvious.

According to Article 346 of the above Act, parties to a case can introduce their attorneys. In addition, Islamic Punishment Act 2013, Section 5, Chapter 10 has stipulated sanctions related to the faults of government officials and authorities. The above provision holds that avoiding legal duties and defamation of people and wasting their rights as stipulated in Iran's Constitution 1979 are subject to criminal sanctions. The following provisions are also in favor of the victim: prohibition of depriving people from their freedom and ignoring their rights as stipulated in Iran's Constitution 1979 (Article 570 of Islamic Punishment Act 2013); hearing complaints before competent courts and forums (Article 572 of Islamic Punishment Act 2013); issuing judgment according to the laws and sanctions of a judge's avoiding to issue the verdict and delay in this regard (Article 597 of Islamic Punishment Act 2013); legality of crimes, punishments and criminal procedure (Articles 12 and 13 of Islamic Punishment Act 2013), and some other issues in the field of fair trail (Hoseini \& Omidi, 2016, p. 34).

Judicial authorities are other main players in administration of justice. Judicial officials and other employees who are working for the Judiciary and human resources related to the file are always considered important organs of Judiciary. A Judiciary who claim that it administers justice and fairness should pay attention to such forces and their needs and should protect them when necessary. We should add that a judge, as a government agent, does not encounter an accused and a normal citizen, rather he sometimes encounters a criminal gang whose forces and power may be more than those of a government (Ashworth, 1998, p. 39).

\subsection{Government Obligations}

Enacting laws with the aim of defining and protecting the victim's rights is not enough if they do not oblige the government to enforce them. Therefore, it is necessary to pay attention to the governments' obligations in addition to defining the victim's rights alongside the enforcement of such rights. Among all the roles, obligations of ministry of justice especially those of public prosecutors, who accomplish investigation and prosecution, are considerable. Public prosecutors' duties include regarding opinions and concerns of the victims when their personal benefits are lost. Governments are obliged to make public prosecutors aware of victims' rights and they should ensure that the victim knows his or her rights (Article 28 of New Criminal Procedure Code 2013).

\section{Conclusions}

Right of a fair trial includes a collection of principles and rules that specify treatment method with a person before the court in different stage and in different cases. Identifying such principles is in connection to the necessity of administration of justice, the principle of equality of human beings before law. They are also related to the principles of the distinction of forces, dependency of the Judiciary, and rule of law. 
Once the following circumstances are recognized and met, we can claim that the right of getting access to a fair trial is secured: different municipal laws and related principles of a fair trial should be safeguarded including independency of the courts and the judges, their impartiality, openness of the court, equal availability of judicial forum for all people, right of defense, right of employing an attorney, right of legal service and the like. Observance of principles of a fair trial requires that the investigation and procedural process of existing files should be carried out based on the observance of the rights of both the accused and the victim. Supervision and control over public prosecutor's office will pave the way for real and effective enforcement of principles of a fair trial. In addition, it fortifies general believes of people in law. As a result of such supervision, we can expect that disciplinary wrongdoing of public prosecutors or judges and other related people will be examined based on legal provisions. Acceptance and emphasis on the enforcement of a fair trial in Iranian legal system indicates the rule of law, independency of the judges and distinction of forces. Verifying New Criminal Procedure Code 2013 is a positive change in terms of predicting and emphasizing the principles of a fair trial. As it was previously mentioned, one of the greatest aims of every judicial system is to get access to complete judicial justice after codifying and verifying the laws. Therefore, if some crimes are committed, they will make a gap in administration of justice. Although Iranian municipal laws in criminal laws have not dealt with this subject independently, they were not ignorant of such an important issue either. Iranian laws stipulated Articles for punishing and sentencing persons who make obstacle in administrating justice.

There is a positive viewpoint for protection of victims in Iranian criminal system. Such a protection is carried out in different forms whether directly or indirectly. Express prohibition of ceasing investigation that should be done by public prosecutor and the investigator and more flexibility in authorities of officials to carry out investigations about the crime can be regarded as grave changes in protecting the victims. It seems that taking security measures and some other protective measures regarding the victim after submitting the complaint are important challenges in Iranian legal system in New Criminal Procedure Code 2013. As an example, By-law for Protecting the Witnesses and the Informed stipulated some protection of witnesses and other persons related to the complaint and hearing. Nevertheless, such cases in protecting the victim are few and have a little legal sanction.

Surely, we should notice that recognition and restitution of legal status of the victims in all stages of criminal process, paying attention to his or her needs during this process and regarding more of spiritual (ethical) rights alongside other rights recognized for them are appropriate paradigm and solution for them to get access to their rights. The author of the present research suggests the following protective measures and mechanisms to make the New Criminal Procedure Code 2013 more protective:

1) Codifying laws and proper solutions to remedy damages incurred by the victim and more participation of the government and multi-governmental organizations to remedy such harm;

2) Recognizing spiritual loss, harm to dignity, emotional and psychological loss to compensate for impaired damages on the victim as a result of the commission of the crime;

3) Enacting laws and programs to carry out medical assistance to perform medical protection of the victim because physical damage needs to be treated before psychological harm;

4) Establishing centers to present psychological counseling to remove emotional and psychological harm originated from commission of the crime;

5) Providing security for victim and witnesses when they come to the criminal courts, which can be accomplished by doing some actions to avoid them from encountering with the accused;

6) Considering separate rooms for parties, witnesses, and their relatives. Moreover, we can predict some arrangements to avoid threatening the victim and witnesses or families and relatives. If they demand for help, police should assist them as soon as possible (Ebrahimi, 2005, p. 323);

7) Predicting some laws to determine an attorney for the victim when he or she is insolvent and payment of lawyer's fee from the fund of administration of justice.

\section{References}

Ashuri, M. (1993). Criminal justice, a collection of articles, principle of innocence and its effects in criminal matters (comparative study) (1st ed.). Tehran: Ganj Danesh Publications.

Ashuri, M. (2013). Criminal procedure (Vol. 1, 7th ed.).

Ashworth, A. (1998). The criminal process: an evaluative study (2nd ed.). London: Oxford University Press.

Beigi, J. (2007). Juvenile victimization in Iranian laws. Tehran: Mizan Publications. 
Dehkhoda, A. (1998). Dictionary (Vol. 11 \& 13). Tehran: Tehran University Press.

Ebrahimi, P. (1995). Victim as a complainant and his or her rights in provisions of criminal procedure. Legal Journal of Department of Justice, 52.

Filzola, J. (2000). Victim and victimology (Roh Allah Kordai Vand and Ahmad Mohammadi, Trans.). Tehran: Majd.

Ghorbani, E., Bigi, J., \& Rasuli, V. (2014). Crimes against judicial justice in the light of international documents. International Conference of Humanities and Behavioral Studies, Tehran: Institute for Managers Creaing ideas Capital Vira.

Hashemi, S. M. (2007). Upgrading victim's status with an approach of restorative justice with a focus on Iranian criminal law, MA thesis at Pardis Qum, Tehran University.

Hoseinlo, H. (2003). Protecting victim in Iran's Criminal Procedure Code with a comparative study with that of France, MA thesis, Emam Sadegh University.

Jafari Langrudi, M. J. (1998). Explanations of legal terminology (Vols. 4 \& 5), 3232.

Lawyers Committee for Human Rights. (2000). What is a fair trial? (A basic guide to legal standards and practice). New York.

Omidi, T., \& Hoseini, S. S. (2016). Analysis of the right to a fair trial in the light of documents of human rights with a look at Iranian laws. Quarterly Journal of Law, 5, 23-40.

Raijian Asli, M. (2004). Three discussions on victimology: municipal, regional and international. Quarterly Journal of Department of Justice, 46.

Raijian Asli, M. (2006). Victims, rights and necessary protections. Journal for research of law and politics, 19.

Saber, M. (2009). Standards and sanctions of a fair trial in preliminary investigations. Journal of Humanities Teacher, Studies of Comparative Law, 4.

Shayan, A. (2005). Justice for victims. UN Office for Control of Addicted Drugs and Prevention of Crime, International Centre for Crime Prevention (Vol. 1). Tehran: Salsabil.

Shiri, A. (2006). Restorative justice (foundations and agents), $\mathrm{PhD}$ dissertation at Shahid Beheshti University.

Shiri, A. (2007). Dignity-based treatment with the victims. Quarterly Journal of Studies of Prevention of Crime, 4.

Shiri, A. (n.d.). Dignity-based treatment with victims. Quarterly Journal of Protective studies, 4.

Siegel, L. J. (2009). Criminology (10th ed.). Thomson Wadsworth.

United Nation Human Rights website-Treaty Bodies Database-document-General comments, General comment No. 16: Right to respect of privacy, family home and correspondence, and protection of honor and reputation (Art. 17): 8/4/88. www.unhchr.ch

\section{Copyrights}

Copyright for this article is retained by the author(s), with first publication rights granted to the journal.

This is an open-access article distributed under the terms and conditions of the Creative Commons Attribution license (http://creativecommons.org/licenses/by/4.0/). 